\title{
Description of Students' Integrated Science Process Skills on Friction Material on a Flat Field
}

\author{
Mashelin Wulandari*, Ricky Purnama Wirayuda, Febritia Aldila, Retno Wulandari \\ Physics Education, Faculty of Teacher Training and Education, Universitas Jambi, \\ Indonesia
}

*Corresponding Author Email: mashelinwulandari@gmail.com

\begin{abstract}
Article History
Received: November 2020

Accepted: December 2020

Published: December 2020

Key Words

Attitude; discipline; junior high school students
\end{abstract}

\begin{abstract}
Science Process Skills have an important function in the process of student curiosity and scholarship, so it is necessary to do a description of students' science process skills. This study aims to describe students' integrated science process skills on friction material on a flat plane at SMPN 9 Muaro Jambi. The observed science process skills consist of ten observation indicators, namely experimental analysis, planning experiments, conducting experiments, describing the relationship between variables, defining variables operationally, making data tables, obtaining and processing data, making hypotheses, identifying variables and making graphs. This type of research is qualitative research with descriptive type. The research subjects were students of class VIII at SMP Negeri 9 Muaro Jambi which consisted of class VIII D and VIII E. The sampling technique was total sampling where the total sample was 40 students. While the data collection technique uses observation sheets that have been validated by a team of experts. The data that has been obtained were analyzed using descriptive statistical techniques with the help of IBM SPSS statistics software. The results of the research on students' mastery of integrated science process skills in the friction practicum on the flat plane were classified into the good category with a percentage of $57.5 \%$. This means that students have good science process skills, because most students are skilled at doing practicum based on experimental indicators. The conclusion of this study shows that the integrated science process skills possessed by students are categorized as good.
\end{abstract}

Wulandari, M., Wirayuda, R., P., Aldila, F., \& Wulandari, R. (2020). Description of students' Integrated Science Process Skills on Friction Material on a Flat Field. Lensa: Jurnal Kependidikan Fisika, 8(2), 93-103. doi:https://doi.org/10.33394/j-1kf.v8i2.3206

\section{INTRODUCTION}

Education is a learning process that develops abilities in a person. Education is a conscious and planned effort to create an atmosphere of learning and learning process so that students (Maison et al., 2019). Education can also be defined as a continuous process that aims to increase the quality of human resource (Darmaji, Kurniawan, \& Suryani, 2019). Education plays an important role in life, because with education a person is able to position himself properly in the family and society (Astalini et al., 2018).

In general, science subjects at the junior high school level are divided into Natural Sciences (IPA) and Social Sciences (IPS). Science is a branch of science that studies the concepts of nature and their application in everyday life (Dari \& Nasih, 2019). Science is also a collection of knowledge, a series of processes and scientific attitudes. Each science has specific characteristics to distinguish it from the others. In general, science subjects cover 3 basic sciences, namely biology, physics, and chemistry. These sciences emerge and develop through the steps of observation, problem formulation, hypothesis preparation, 
hypothesis testing through experiments or experiments, drawing conclusions, and finding theories and concepts (Gasila et al., 2019).

In essence, physics is a branch of natural science that deals with the symptoms and properties of objects in nature. Physics learning is an important subject because it is the most basic learning (Darmaji, Kurniawan, Astalini, \& Nasih, 2019). Physics is usually always seen as a difficult subject for students so that not many students are interested in learning something related to physics(Maison et al., 2019). Assessment in physics learning is not only on the cognitive and affective aspects, but also considers psychomotor assessments (Dari \& Nasih, 2019). At the junior high school level (SMP) there are subjects that study the concepts of nature and everyday life, namely Natural Sciences related to science. Generally science lessons in junior high schools are taught by science teachers, who organize teaching and learning activities.

The conventional physics teaching process makes students tend to only master the concepts of physics, but do not know the process of these concepts. In addition, students will also quickly get bored because it is difficult to imagine events in true and concrete science (Ningsi \& Nasih, 2020). To understand the concepts in physics learning, cognitive and affective aspects are not enough. For example, by just learning in class and discussing the questions. But students also need direct experience in terms of psychomotor aspects. One of the efforts that the teacher can make to improve students' understanding in learning physics is to do a practicum so that they can see the understanding and process skills of students in learning physics. This is also stated by (Nyoman \& Putu, 2014) ) that this activity is the most important method in learning physics, where concepts will be easier to understand if they have experienced, seen and worked on their own.

One of the goals of national education is that students are able to develop experiences through experiments in order to formulate problems, propose and test hypotheses, design and assemble instruments, collect, process and interpret data, and communicate orally and in writing. A number of these skills.

One of the goals of national education is that students are able to develop their potential through experiments or experiments which consist of various skills such as formulating problems, making hypotheses, designing and conducting experiments, collecting and processing data and drawing conclusions. These skills are called science process skills (Tyas et al., 2020). Science process skills are the ability to process actions as well as scientific thinking, in order to develop an understanding of scientific concepts to support subsequent abilities (Darmaji, Kurniawan, Parasdila, et al., 2018). In addition, science process skills can be interpreted as skills that are used to seek information, think about a problem and formulate ways to solve the problem (Darmaji, Astalini, et al., 2018). Students' science process skills must be supported by understanding of the fields of mathematics and science to support the success of the experiment in the laboratory (Darmaji, Kurniawan, Astalini, Kurniawan, et al., 2019). Science process skills can be developed through practical activities. This practicum activity can be used as an activity to improve and develop students' scientific skills, including one of the psychomotor aspects (Darmaji, Kurniawan, Suryani, et al., 2018).

According to Turiman et al (2012) in (Darmaji, Kurniawan, Parasdila, et al., 2018) science process skills can be classified into basic process skills and integrated process skills. Basic process skills consist of observing, summarizing, measuring, communicating, classifying, predicting, using time and space relationships and using numbers. Meanwhile, integrated process skills consist of identifying variables, creating data tables, making graphs, describing relationships between variables, obtaining data, processing data, analyzing, designing hypotheses, defining variations operationally, designing 
investigations and experimenting. Science process skills observed in this study are integrated science process skills. These science process skills include experimental analysis, planning experiments, conducting experiments, describing relationships between variables, defining variables operationally, creating data tables, obtaining and processing data, making hypotheses, identifying variables, and making graphs. One of the materials in physics lessons that can be used to determine students' science process skills is the friction material on a flat plane.

Frictional force is a force in the direction opposite to the direction the object is moving or the direction the object tends to move. Frictional force can occur when two objects touch each other. These objects can be solid, liquid, or gas. For example, the frictional force that occurs between two solid objects is the static friction force and the kinetic friction force. While the friction force that occurs between solid objects with liquids and gases is the stokes force (Agus et al., 2015). The friction force is symbolized by the letter F (Friction) and if it arises on a stationary object it is called the static friction force (Ginting et al., 2018). Friction on a flat plane occurs on a rough flat plane where the value of the friction force will be proportional to the normal force and the static friction coefficient (Zuhdi \& Supriyadi, 2019).

This research was conducted to determine students' science process skills on flat plane friction material. Similar research has been conducted by Gusdiantini et al (2017). who developed students' science process skills on friction material through a contextual approach. The aim is to determine the improvement of students' science process skills in the material of friction through a contextual approach that discusses basic science process skills in the form of observing, classifying, predicting, designing experiments, interpretation skills, communication skills. Where only discussed the improvement of overall science process skills. Meanwhile, this study will discuss students' integrated science process skills on flat plane friction material which will be described based on 10 indicators. Therefore, this study aims to determine the integrated science process skills possessed by students at SMP Negeri 9 Muaro Jambi on friction material. The indicators used in this study are experimental analysis skills, planning experiments, conducting experiments, describing the relationship between variables, defining variables operationally, creating data tables, obtaining and processing data, making hypotheses, identifying variables, and making graphs.

\section{METHOD}

The research method used is quantitative research with descriptive type. Quantitative research is research whose data results in the form of numbers and research data are analyzed using statistical data (Winarsunu, 2017). This quantitative research is used to find out an overview of the integrated science process skills possessed by students in science lessons, especially physics, friction material on a flat plane. The data analysis technique used in this research is descriptive statistics and the data analysis is statistical analysis with the help of IBM SPSS statistics software.

This research was conducted in November 2020 with the subjects of this study were students of SMP Negeri 9 Muaro Jambi in the odd semester of the 2020/2021 school year. The study population was all students of class VIII D and VIII E SMP Negeri 9 Muaro Jambi, while the sample used was 40 students from class VII D and VIII E. The sampling used was total sampling technique. While the data analysis technique used in this study is descriptive statistics and data analysis is statistical analysis with the help of IBM SPSS statistical software. 
The instrument used in this study was an observation sheet of students' science process skills on friction material that had been validated by a team of experts. This observation sheet is used to determine the students' mastery of science process skills. The focus of this research is the integrated science process skills possessed by students when conducting experiments. The approach used in this observation sheet is to use a Likert scale with four points or four score scales. The Likert scale is a scale used as a measuring tool for a person's perception (Situmorang, 2010). While the score scale is used to determine student effectiveness (Priyadi et al., 2015) in this case the students' science process skills. The science process skill scores given to students consisted of four categories, namely $1=$ very bad (VB), $2=$ bad (B), $3=\operatorname{good}(\mathrm{G})$, and $4=\operatorname{very}$ good VG).

The range of categories used to see the category of scientific processes that students have based on the scores or scores obtained by students on the science process skills observation sheet. Assessment of the value of skills skills obtained by students in Table 1 below.

Table 1. Range of categories for the assessment of Science Process Skills

\begin{tabular}{cc}
\hline Value Range & Category \\
\hline $149.51-184$ & Very Good \\
$115.01-149.5$ & Good \\
$80.51-115$ & Bad \\
$46-80.5$ & Very Bad \\
\hline
\end{tabular}

Meanwhile, to determine the mastery of science process skills that students have for each indicator is presented in table 2 below.

Table 2. Range of Science Process Skills Assessment Categories in Each Indicator

\begin{tabular}{|c|c|c|c|c|}
\hline \multirow{2}{*}{$\begin{array}{c}\text { Indicator Integrated Science } \\
\text { Process Skills }\end{array}$} & \multicolumn{4}{|c|}{ Value Range } \\
\hline & VB & B & G & VG \\
\hline Experimental Analysis & $3-5.25$ & $5.26-7.5$ & $7.51-9.75$ & $9.76-12$ \\
\hline Experimental planning skills & $7-12.25$ & $12.26-17.5$ & $17.51-22.75$ & $22.76-28$ \\
\hline $\begin{array}{l}\text { Experimentation skills } \\
\text { Skills to describe the relationship }\end{array}$ & $14-24.5$ & $24.51-35$ & $35.01-45.5$ & $45.51-56$ \\
\hline $\begin{array}{l}\text { between variables } \\
\text { Skills to define variables }\end{array}$ & $2-3.5$ & $3.51-5$ & $5.01-6.5$ & $6.51-8$ \\
\hline operationally & $4-7$ & $7.01-10$ & $10.01-13$ & $13.01-16$ \\
\hline Membuat tabel data & $4-7$ & $7.01-10$ & $10.01-13$ & $13.01-16$ \\
\hline $\begin{array}{l}\text { Data acquisition and processing } \\
\text { skills }\end{array}$ & $6-10.5$ & $10.51-15$ & $15.01-19.5$ & $19.51-24$ \\
\hline Hypothesis skills & $1-1.75$ & $1.76-2.5$ & $2.51-3.25$ & $3.36-4$ \\
\hline Variable identification skills & $3-5.25$ & $5.26-7.5$ & $7.51-9.75$ & $9.76-12$ \\
\hline Graphing skills & $2-3.5$ & $3.51-5$ & $5.01-6.5$ & $6.51-8$ \\
\hline
\end{tabular}

\section{RESULTS AND DISCUSSION}

The research conducted was to observe students' integrated science process skills on friction material on a flat plane. Science process skills are the ability to process actions as well as scientific thinking, in order to develop an understanding of scientific concepts to support subsequent abilities (Darmaji, Kurniawan, Parasdila, et al., 2018). Science process skills are used as an activity to improve the psychomotor aspects of students. Science process skills can be obtained through integrated science process skills which are the development of basic science process skills (Ningsi \& Nasih, 2020). This study involved 
40 students from class VIII D and VIII E at SMP Negeri 9 Muaro Jambi. This observation was carried out based on 10 indicators of students' integrated science process skills. The total number of statements on the student's integrated science process skills observation sheet consisted of 46 statements. The results of observations on students' mastery of integrated science process skills on friction material on this flat plane are shown in table 3 below.

Table 3. Students' Mastery of Integrated Science Process Skills on Friction Material on a Flat Field

\begin{tabular}{llllllll}
\hline Value Range & Category & f & \% & Mean & Median & Min & Max \\
\hline $149.51-184$ & Very Good & 4 & 10 & & & & \\
$115.01-149.5$ & Good & 23 & 57.5 & & & & \\
$80.51-115$ & Tidak baik & 10 & 25 & 125.325 & 127.50 & 80.00 & 154.00 \\
$46-80.5$ & Sangat tidak baik & 3 & 7.5 & & & & \\
\hline
\end{tabular}

Based on table 3 above, it can be seen that the results of students' integrated science process skills on friction material on the flat plane are in the good category with a percentage of $57.5 \%$ or as many as 23 people out of 40 students are in the good category. The average score for integrated science process skills was 125.325 and the median was 127.50. The minimum score obtained by students is 80 with the maximum score obtained is 154 .

This observation was carried out by observing 10 indicators of students' integrated science process skills. These integrated science process skills include experimental analysis, planning experiments, conducting experiments, describing relationships between variables, defining variables operationally, making data tables, obtaining and processing data, making hypotheses, identifying variables and making graphs. The results of these observations are shown in Table 4 below.

Table 4. Students' Mastery of Integrated Science Process Skills in Each Indicator

\begin{tabular}{|c|c|c|c|c|}
\hline \multirow{2}{*}{ Indicator Integrated Science Process Skills } & \multicolumn{4}{|c|}{ Category } \\
\hline & VB (\%) & B (\%) & G (\%) & VG (\%) \\
\hline Experimental analysis skills & 12.5 & 37.5 & 30.0 & 20.0 \\
\hline Experimental planning skills & 7.5 & 27.5 & 42.5 & 22.5 \\
\hline Experimentation skills & 12.5 & 15 & 42.5 & 30 \\
\hline $\begin{array}{l}\text { Skills to describe the relationship between } \\
\text { variables }\end{array}$ & 20 & 37.5 & 30 & 12.5 \\
\hline Skills to define variables operationally & 22.5 & 20 & 45 & 12.5 \\
\hline Data table creation skills & 10 & 15 & 50 & 25 \\
\hline Data acquisition and processing skills & 7.5 & 30 & 45 & 17.5 \\
\hline Hypothesis skills & 12.5 & 27.5 & 37.5 & 22.5 \\
\hline Variable identification skills & 17.5 & 25 & 45 & 12.5 \\
\hline Graphing skills & 12.5 & 60.0 & 17.5 & 10.0 \\
\hline
\end{tabular}

\section{Experimental analysis skills}

In the experimental analysis indicator, the results obtained showed that $37.5 \%$ of the 40 students were in the bad category. This shows that as many as 15 students have science process skills on indicators of analyzing experiments that are still not good. This indicator can be seen through the activities carried out by students when adjusting the experimental design with the hypotheses that have been previously made. According to Darmaji, Kurniawan, Parasdila, et al (2018) when students conduct an experimental analysis, 
students will find patterns that can predict conditions that have not happened or been observed. Based on the research results, there are still many students who have not been able to decide that the experimental design is in accordance with the hypothesis or not.

\section{Experimental planning skills}

On the indicator of planning the experiment, the results obtained show that $42.5 \%$ of the 40 students belong to the good category. This indicator can be seen from how the students' skills are in determining what main tools and materials are used in the friction experiment on a flat plane. On the indicator of planning experimental skills, students are said to have good skills where students are able to carry out activities that support mastery of these skills (Ningsi \& Nasih, 2020). Based on the results of the study, most students were able to determine the steps of work in this experiment in accordance with the guidance given without having to be ordered by the researcher first.

\section{Experimentation skils}

On the indicators of conducting an experiment, the results obtained showed that $42.5 \%$ of the 40 students belonged to the good category. The indicators of conducting this experiment can be seen from how the skills of students when preparing tools and materials are in accordance with the objectives of the experiment and according to the guidance given, determining the side of the beam used in the friction experiment on a flat plane, determining the length of the rope, arranging the tools on the skateboard, distinguishes objects from loads, determines the mass of the object and the load then compares which one has the greater mass to determine the time it takes for the object to start moving to stop using a stopwatch. Students' science process skills in conducting experiments, student scores are in a good category, this can happen because students feel happy when practicum activities take place (Tyas et al., 2020). Based on the results of research on this indicator, the dominant students already know how to do practicum properly in accordance with the procedures and guidelines given.

\section{Skills to describe the relationship between variables}

On indicators describing the relationship between variables, the results obtained show that $37.5 \%$ of the 40 people are in the bad category. The skill indicator describing the relationship between these variables can be seen based on when students make a line that matches the relationship between the mass of the beam 1 and the mass of the block 2 from the slide and makes a line that matches the relationship between distance and time when the object moves on a flat. Darmaji, Kurniawan, Parasdila, et al (2018) also said that when students observe the relationship between variables, patterns will be found that can predict conditions that have not yet occurred or been observed. Based on the research results that have been observed, students are still unable to describe the relationship between variables so that students find it difficult to discuss the results with their respective groups in the graph of the relationship between block mass 1 and block mass 2 and the relationship between distance and time required by objects.

\section{Skills to define variables operationally}

In the indicator that defines the variables operationally, the results obtained are $45 \%$ of the 40 students are in the good category. Students' skills in this indicator can be seen when students measure the mass of blocks and the mass of the load using a spring balance, measure the distance of objects and the length of the rope using a ruler, and calculate the time to carry out experiments using a stopwatch. In addition, this skill can be supported by the ability of students to conclude experiments, in which concluding mastery will support the ability to define variables operationally (Ningsi \& Nasih, 2020). Based on the 
results of the research obtained, some students were able to measure the mass of the beam, the mass of the load, the distance, and calculate the time correctly.

\section{Data table creation skills}

On the indicators of making data tables, the results obtained are $50 \%$ of the 40 students are in the good category. In this indicator, it can be seen from how students make column headings for each column. In addition, it can also be seen based on when students made repeated data tables for each experiment and made column numbers that clarified the existence of repeated measurements. The research conducted by (Tyas et al., 2020) also said that the skills of students related to making tables and processing data were classified as good. Based on the results of the study, the dominant students were able to make data tables from the experiments carried out in accordance with the requested table.

\section{Data acquisition and processing skills}

On the indicators of skills in obtaining and processing data, the results obtained were $45 \%$ of the 40 students were in the good category. This indicator can be seen when students make tables of experimental data, make measurement repetition tables, make graphs that describe the relationships between variables, and discuss to draw conclusions from the experiments carried out. This is also in line with research by Nyoman \& Putu (2014) which states that data processing skills or interpreting data are carried out by connecting one thing with another. On the indicators, although there are some students who are constrained in making graphs that describe the relationship between variables, students have been able to obtain and process data well, especially the data from measurements in table form.

\section{Hypothesis skills}

On the skill indicators to make hypotheses, the results obtained were $37.5 \%$ of the 40 students were in the good category. Students' skills in this indicator can be seen when students make hypotheses from friction experiments on a flat plane, then design the experiment according to the hypothesis. Students' skills in making hypotheses are classified as good, because students are able to make observations in practicum activities and also make hypotheses (Darmaji, Kurniawan, Parasdila, et al., 2018). Based on the results of the study, on this indicator most students were able to hypothesize experimental friction on a flat plane.

\section{Variable identification skills}

On the indicator of variable identification skills, the results obtained were $45 \%$ of the 40 students were in the good category. Students' skills in this indicator can be seen when students determine the experimental variables. These variables consist of independent variables, dependent variables and control variables. In the skill of determining this variable, students are asked to identify and differentiate which are the independent variables, control variables and dependent variables. The skill of identifying variables is in a good category, which shows that students are able to find patterns that can predict conditions that have not yet happened. (Darmaji, Kurniawan, Parasdila, et al., 2018). Based on the results of the study, most students were able to distinguish the variables in the experiment.

\section{Graphing skills}

On the skill indicator in making graphs, the results obtained are $60 \%$ of the 40 students are in the bad category. Students' skills in this indicator can be seen when students graph the relationship between the mass of the block and the mass of the load and graph the relationship between distance and time. According to (Hasanah et al., 2016) the factor 
that causes students' lack of skills in making graphics is that physics learning is still limited to verbal and mathematical representation skills, so students have difficulty making graphics. Based on the results of the study, on this indicator the dominant student still cannot graph the experimental results correctly, namely the relationship between the mass of the beam and the mass of the load and the relationship between distance and time.

Practicum is one of the activities that is considered effective in helping students improve their understanding of subject matter and concepts, so that students can remember lessons and gain experience directly through these activities (Qosim \& Handhika, 2020). This is in accordance with the results of the observations obtained, where the integrated science process skills that students have are categorized as good. This situation shows that this practicum activity is very helpful for students, where through the friction practicum activity on this flat area students have understood many concepts that were previously still not understood.

\section{CONSLUSSION}

Based on the results of the observation sheet data analysis, it can be concluded that the students' integrated science process skills on friction material on a flat plane are in the good category. This is shown in the results of the research statistics, namely $57.5 \%$. Most of the students showed good science process skills on experimental indicators. The indicator of integrated science process skills which is in the good category, the most dominant is the indicator of making data tables. The results show that the percentage obtained is $50 \%$. These results indicate that the integrated science process skills possessed by students are good, where students can carry out a series of experimental procedures without having to be guided as a whole by the researcher.

\section{RECOMMENTATION}

The results of this study are an initial description of students 'integrated science process skills with the hope that through this research it can improve students' science process skills through practicum activities. Although the science process skills possessed by dominant students are categorized as good, there are still several indicators of the students' science skills processes that are in the bad or poor category. This is due to the lack of students' knowledge in understanding the experiment and changing the form of the experimental results. As in the indicators of analyzing experiments, identifying relationships between variables, obtaining and processing data, and making graphs. This needs to be given better attention by teachers and researchers who conduct research so that students can get good results on all observation indicators.

\section{ACKNOWLEDGMENTS}

Researchers would like to express their deepest gratitude to the family who always support, the supervisor who always provides directions, all SMP Negeri 9 Muaro Jambi who have given permission and allowed researchers to carry out research, as well as to friends and all parties who have helped and simplify the researcher's business so that the researcher can complete this research until the end.

\section{REFERENCES}

Agus, B., Darmanto, \& Syafaat, I. (2015). Karakterisasi Koefisien Gesek Permukaan Baja ST 37 Pada Bidang Datar Terhadap Viskositas Pelumas. Momentum, 8(2), 11-18.

Astalini, A., Kurniawan, D. A., \& Putri, A. D. (2018). Identifikasi Sikap Implikasi Sosial dari IPA, Ketertarikan Menambah Waktu Belajar IPA, dan Ketertarikan Berkarir Dibidang IPA Siswa SMP Se-Kabupaten Muaro Jambi. Jurnal Tarbiyah : Jurnal Ilmiah 
Kependidikan, 7(2), 93-108. https://doi.org/10.18592/tarbiyah.v7i2.2142

Dari, R. W., \& Nasih, N. R. (2019). Identifikasi Tingkat KPS Mahasiswa Praktikum Pembiasan Kaca Plan Paralel Menggunakan Panduan Praktikum Berbasis E-Modul. JIFP (Jurnal Fisika Dan Pembelajarannya), 3(2), 47-57.

Darmaji, Astalini, Rahayu, A., \& Maison. (2018). Pengembangan Penuntun Praktikum Fisika Berbasis Keterampilan Proses Sains Menggunakan Model Problem Solving. 2018, 10(1), 83-96. https://doi.org/http://dx.doi.org/10.15408/es.v10i1.7248

Darmaji, Kurniawan, D. A., Astalini, Kurniawan, W., Anwar, K., \& Lumbantoruan, A. (2019). Students' perceptions of electronic's module in physics practicum. Journal of Education and Learning (EduLearn), 13(2), 288-294. https://doi.org/10.11591/edulearn.v13i2.13005

Darmaji, Kurniawan, D. A., Astalini, \& Nasih, N. R. (2019). Persepsi Mahasiswa pada Penuntun Praktikum Fisika Dasar II Berbasis Mobile Learning. Jurnal Pendidikan: Teori, Penelitian, Dan Pengembangan, 4(4), 516-523.

Darmaji, Kurniawan, D. A., Parasdila, H., \& Irdianti. (2018). Deskripsi Keterampilan Proses Sains Mahasiswa pada Materi Termodinamika. Berkala Ilmiah Pendidikan Fisika, 6(3), 345-353. https://doi.org/10.20527/bipf.v6i3.5290

Darmaji, Kurniawan, D. A., \& Suryani, A. (2019). Effectiveness of Basic Physics II Practicum Guidelines Based On Science Process Skills. JIPF (JURNAL ILMU PENDIDIKAN FISIKA), 4(1), 1-7. https://doi.org/10.26737/jipf.v4i1.693

Darmaji, Kurniawan, D. A., Suryani, A., \& Lestari, A. (2018). An Identification of Physics Pre-Service Teachers' Science Process Skills Through Science Process SkillsBased Practicum Guidebook. Jurnal Ilmiah Pendidikan Fisika Al-BiRuNi, 7(2), 239245. https://doi.org/10.24042/jipfalbiruni.v7i2.2690

Gasila, Y., Fadhillah, S., \& Wahyudi. (2019). Analisis Keterampilan Proses Sains Siswa dalam Menyelesaikan Soal IPA di SMP Negeri Kota Ponyianak. Jurnal Inovasi Dan Pembelajaran Fisika (JIPF), 6(1), 14-22.

Ginting, M., Yusuf, M., Prasetyo, R. A., Sriwijaya, P. N., \& Besar, B. (2018). Analisa koefisien gesek pelumas mesin multi grade. Jurnal Austenit, 10(2), 61-66.

Gusdiantini, L., Aeni, A. N., \& Jayadinata, A. K. (2017). Pengembangan Keterampilan Proses Sains Siswa Kelas V Pada Materi Gaya Gesek Melalui Pembelajaran Kontekstual. Jurnal Pena Ilmiah, 2(1), 651-660. https://doi.org/10.17509/jpi.v2i1.10103

Hasanah, H., Mahardika, I. K., \& Supriadi, B. (2016). Penerapan Model Pembelajaran Inkuiri Disertai LKS Berbasis Multirepresentasi terhadap Keterampilan Proses Sanis dan Hasil Belajar Siswa dalam Pembelajaran Fisika di SMAN Kabupaten Jember. Jurnal Pembelajaran Fisika, 5(2), 135-140.

Maison, Darmaji, Kurniawan, D. A., Astalini, Dewi, U. P., \& Kartina, L. (2019). Analysis of Science Process Skills in Physics Education Students. Jurnal Penelitian Dan Evaluasi Pendidikan, 51(1), 197-205.

Ningsi, A. P., \& Nasih, N. R. (2020). Mendeskripsikan Keterampilan Proses Sains Mahasiswa Pendidikan Fisika Universitas Jambi pada Materi Pembiasan pada Lensa Cembung dengan Menggunakan E-Modul. EKSAKTA: Jurnal Penelitian Dan Pembelajaran MIPA, 5(1), 35-43.

Nyoman, N., \& Putu, S. (2014). Meningkatkan Keterampilan Proses Sains Mahasiswa Melalui Pengembangan Program Pembelajaran Fisika. Jurnal Ilmiah Pendidikan Fisika "Lensa," 1(2), 125-132.

Priyadi, R., Maison, \& Kurniawan, W. (2015). Pengembangan Kuis Interaktif Pembelajaran Fisika Pada Materi Hukum Newton Tentang Gravitasi Dengan 
Menggunakan Program Wondersharequiz Creator 4.5.1. Repository Universitas Jambi, $1(1), 1-6$.

Qosim, M. Y., \& Handhika, J. (2020). Profil Analisis Kebutuhan Pengembangan Media Praktikum Gaya Gesek untuk Meningkatkan Keterampilan Proses Sains Siswa SMAN 2 Jiwan. PROSIDING Seminar Nasional Pendidikan Fisika FITK UNSIQ, 2(1).

Situmorang, S. H. (2010). Analisis Data: untuk Riset Manajemen dan Bisnis. USU Press.

Tyas, R. A., Wilujeng, I., \& Suyanta, S. (2020). Pengaruh pembelajaran IPA berbasis discovery learning terintegrasi jajanan lokal daerah terhadap keterampilan proses sains Science learning based on discovery integrated regional local snacks on student science process skills. Jurnanovasi Pendidikan IPA, 6(1), 114-125.

Winarsunu, T. (2017). Statistik dalam Penelitian Psikologi dan Pendidikan (Pertama). Universitas Muhammadiyah Malang.

Zuhdi, M., \& Supriyadi. (2019). Desain dan Pembuatan Alat Uji Koefisien Gesek Berdasarkan Sudut Kemiringan Bidang Longsor. Jurnal Pijar MIPA, 14(3), 192-196. 